\title{
Characteristics of Cucumber mosaic virus Infecting Zucchini in Korea
}

\author{
Mi-Kyeong Kim ${ }^{1,6}$, Hae-Ryun Kwak ${ }^{1}$, Seon-Gi Jeong ${ }^{2}$, Sug-Ju Ko ${ }^{3}$, Su-Heon Lee ${ }^{1}$, Jeong-Soo Kim ${ }^{1}$, \\ Kook-Hyung Kim ${ }^{4}$, Jang-Kyung Choi ${ }^{5}$, Hong-Soo Choi ${ }^{*}$ and Byeong-Jin Cha ${ }^{6 *}$ \\ ${ }^{1}$ Agricultural Microbiology Division, National Academy of Agricultural Science, Suwon 441-707, Korea \\ ${ }^{2}$ Gyeongsangnam-do Agricultural Research and Extension services, Jinju 660-360, Korea \\ ${ }^{3}$ Jeonnam Agricultural Research and Extension Services, Kurye 542-821, Korea \\ ${ }^{4}$ Department of Agricultural Biotechnology and Plant Genomics and Breeding Institute, Seoul National University, Seoul 151- \\ 921, Korea \\ ${ }^{5}$ Department of Agricultural Biology, Kangwon National University, Chunchon 200-701, Korea \\ ${ }^{6}$ Department of Plant Medicine, Chungbuk National University, Cheongiu 361-763, Korea \\ (Received on January 18, 2010; Accepted on May 18, 2010)
}

\begin{abstract}
A virus causing stunt, yellowing, severe mosaic, malformation symptoms on leaves and uneven development and malformation on fruits of zucchini was prevalent around Goseong, Gyeongsangnam-do, Korea. A survey conducted (2004) in the Goseong area revealed about $20 \%$ virus infection rate. The disease causative identified as Cucumber mosaic virus (CMV-Z1) was further characterized. The isolate induces mosaic symptoms on Cucumis sativus, while severe mosaic, stunt and malformation on $C$. pepo. Thin section analyses have shown that virus inclusions are formed in the cuticle layers as well as epidermal, parenchyma and collenchymas cells in virus-infected Nicotiana tabacum. CMV-Z1 isolate induced specific cytoplasmic inclusion bodies such as irregular clumps (IC), crystal (Cr) and irregular chloroplasts (ICh). IC was made up of virus particles interspersed with a darkly stained amorphous material and found both in the cytoplasm and vacuoles, whereas ICh and $\mathrm{Cr}$ were rarely found in the vacuoles. The genome of CMV-Z1 RNA-1 consists of 3359 nucleotide (nt) encoding 1a protein of 993 amino acids (aa). The CMVZ1 RNA-2 was $3050 \mathrm{nt}$ in length containing 2a (857 aa) and $2 b$ (110 aa), while RNA-3 encoding $3 a$ movement protein (279 aa) and coat protein (218 aa) was $2215 \mathrm{nt}$ in length. Phylogenetic analyses of nucleotide sequences of CMV-Z1 isolate appeared it is more closely related to subgroup IA than to subgroup IB or II.
\end{abstract}

Keywords : CMV, complete genome sequence, phylogenetic analysis, zucchini

\footnotetext{
*Co-Corresponding authors.

Hong-Soo Choi

Phone) +82-31-290-0401, FAX) +82-31-290-0434

E-mail) hschoi@korea.kr

Byeong-Jin Cha

Phone) +82-43-261-2557, FAX) +82-43-271-4414

E-mail)bjcha@chungbuk.ac.kr
}

Cucumber mosaic virus (CMV) occurs world-widely in nature and has the broadest host range among known viruses, infecting more than 1,200 species of plants from monocotyledons to dicotyledons, from herbaceous plants to trees. CMV is transmitted primarily by aphids, and also by seeds, cucumber beetles, parasitic plants, humans, and mechanically (Doolittle, 1916; Edwardson and Christie, 1991; Jagger, 1916). Although the most common symptom incited by CMV is mosaic (Doolittle, 1916; Wellman, 1972), severity of disease may range from no obvious symptom in some crops to death of host species (Van Regenmortel et al., 2000). Some of the intermediate symptoms include blight, fernleaf, ringspot, fruit woodiness and necrosis of bulbs and fruit (Wellman, 1972). The genome of CMV consists of three genomic RNAs (1,2 and 3), as well as the two subgenomic RNAs (4 and 4A). All the RNAs have a cap structure at the $5^{\prime}$ terminus and $3^{\prime}$ portion and also highly conserved in virus-specific manner (Roossinck, 2001; Symons, 1975).

CMV, the type species in the genus Cucumovirus, family Bromoviridae, is single-stranded, positive-sense RNA virus (Palukaitis and Garcia-Arenal, 2003; Roossinck et al., 1999; Suzuki et al., 1991). Serological data, peptide mapping of coat pretein (CP), and nucleic acid hybridization divided CMV strains into three subgroups: IA, IB and II (Chaumpluk et al., 1996; Roossinck et al., 1999). Meanwhile, phylogenetic analyses of individual RNA, gene or even entire genome revealed further subspeciation due to radial evolution (Roossinck, 2002) and, therefore, were used for a complete phylogenetic analysis of the virus.

In Korea, various viruses including CMV, Watermelon mosaic virus (WMV), Zucchini yellow mosaic virus (ZYMV), Papaya ringspot virus, Kyuri green mottle mosaic virus and Zucchini green mottle mosaic virus were identified from zucchini plants (Choi, 2001; Jin, 2003; Lee, 1981; Lee et al., 2003). In addition, Choi et al. (1998) 
reported that eight isolates of CMV were identified and differentiated by dsRNA analysis, RT-PCR assay, MspI restriction mapping, SSCP analysis, serological property, and biological reactions in several hosts. In this study, we isolated $\mathrm{CMV}$ isolates from zucchini and compared its characteristics to the other CMV strains using biological, serological, and cytological properties. Additionally, we sequenced the complete genome of CMV RNAs 1, 2, and 3 and analyzed phylogentic relationship to the other previously reported CMV strains.

\section{Materials and Methods}

Virus isolate and host range studies. A survey of zucchini and Hemistepta lyrata Bunge virus disease was carried out in Goseong, Gyeongsangnam-do, Korea, in 2004. To isolate pure CMV cultures from possible double infections, virus isolates were inoculated to local lesion host (Nicotiana tabacum cv. Xanthi-nc) and reisolated from local lesions at 7-14 days postinoculation at least three times in succession. To determinate the infectivity of virus isolates and the symptoms induced on test plants, 5-10 plant seedlings of each of the species listed in Table 2 at the 3-5 leaf stage were mechanically inoculated using sap prepared by homogenizing infected leaf samples in $0.01 \mathrm{M}$ phosphate buffer, $\mathrm{pH}$ 7.0. Inoculated plants were maintained in an insect-free greenhouse at $20-25^{\circ} \mathrm{C}$. Disease symptoms were checked three times a week for 30 days. Enzyme linked immunosorbent assay (ELISA) and examination with the naked eye verified both symptomatic and non-symptomatic plants for CMV infection.

ELISA. ELISA test kits purchased from Agdia (USA) were used. CMV polyclonal antibodies and conjugate were both diluted 1:500 and all incubations were carried out at $37^{\circ} \mathrm{C}$ for $2 \mathrm{~h}$ except for the substrate which was incubated for $30 \mathrm{~min}$. Finally, quantitative measurements of generated p-nitrophenol were made by absorbance at $405 \mathrm{~nm}$ spectrophotometer (EL312e EIA, Bio-Tek Instruments Inc., USA). Absorbance value higher than twice of negative control was considered as positive.

Purification. Virus was purified following Takanami (1981), Lot and Kaper (1976) and Mossop et al. (1976) with modification. CMV- infected tabacco (Nicotiana tabacum cv. Xanthi-nc) leaves were homogenized with chilled blender jar with 1:5 (w/v) volume of $0.5 \mathrm{M}$ sodium citrate buffer (SCTB, pH 7.0) containing $5 \mathrm{mM}$ EDTA and $0.5 \%$ 2-mercaptoethanol and filtered through several layers of cheesecloth. The extract was strained, stirred with $8 \%(\mathrm{v} / \mathrm{v})$ chloroform: butanol at $4{ }^{\circ} \mathrm{C}$ for $30 \mathrm{~min}$ and centrifuged at $8,000 \mathrm{rpm}$ at $4^{\circ} \mathrm{C}$ for $30 \mathrm{~min}$. The supernatant was adjusted to $8 \%$ polyethylene glycol (PEG, MW 6,000) and $0.1 \mathrm{M}$ sodium chloride and incubated $1 \mathrm{hr}$ at $4{ }^{\circ} \mathrm{C}$ with continuous stirring. Pellets saved after centrifugation were resuspended with $100 \mathrm{ml}$ of $0.05 \mathrm{M}$ SCTB containing $5 \mathrm{mM}$ EDTA and $2 \%$ Triton $\mathrm{X}-100$. The supernatant was precipitated by ultracentrifugation at $40,000 \mathrm{rpm}$ for $2.5 \mathrm{hrs}$ at $4^{\circ} \mathrm{C}$ and each pellet was resuspended with $1 \mathrm{ml}$ of $0.05 \mathrm{M}$ SCTB. The resulting solution was centrifuged at $8,000 \mathrm{rpm}$ for 30 min. The supernatant was centrifuged at $40,000 \mathrm{rpm}$ for 2.5 hrs and pellet was resuspended in $0.05 \mathrm{M}$ SCTB. Aliquots were subjected to two cycles of sucrose density gradient centrifugation at $28,000 \mathrm{rpm}$ for $2 \mathrm{hrs}$. Separated virus layer was dialyzed and centrifuged at 40,000 rpm for $2 \mathrm{hrs}$. Pellets were dissolved into $\mathrm{ddH}_{2} \mathrm{O}$.

Electron microscopy (EM). Dip preparations were prepared by grinding a small piece of infected $N$. tabacum with 2-3 drops of $2 \%$ phosphotungstic acid, $\mathrm{pH}$ 7.0. The extract was mounted on a carbon-stabilized and Formvarcoated grid. For transmission EM, infected leaves were harvested two weeks after inoculation and immediately cut with a sharp blade into 1-3 mm thick pieces. The pieces were immediately fixed with $2.5 \%$ glutaraldehyde in Millonig's phosphate buffer, $\mathrm{pH} 7.0$ and stored at $4{ }^{\circ} \mathrm{C}$. After rinse with Millonig's phosphate buffer and postfix with $2 \%$ osmium tetraoxide for $90 \mathrm{~min}$, the pieces were stained overnight in $1.0 \%$ uranyl acetate at $4{ }^{\circ} \mathrm{C}$ and then rinsed with distilled water. Stained pieces were dehydrated with 50 $100 \%$ ethanol series for $50 \mathrm{~min}$ and embedded in spur resin. Embedding blocks were hardened overnight at $60^{\circ} \mathrm{C}$ and then sliced to $80 \mathrm{~nm}$ thickness using ultramicrotome. The sections were then stained twice, with $2 \%$ uranyl acetate for $20 \mathrm{~min}$ and with $0.5 \%$ lead citrate for $10 \mathrm{~min}$. For interpretation of results, the sections were observed under electron microscope (LEO 912AB (Carl Zeiss, Germany) at $80 \mathrm{kV}$.

Primers. The primers were designed to sequence fulllength genome of each RNAs based on the previously reported sequences of CMV available in GenBank of National Center for Biotechnology (NCBI, USA; Table 1). A modification and reformulation of $\mathrm{CMV}$ primers previously described was necessary for their use as external primers (Rizos et al., 1992). Genus primers were designed from these alignments for RNA1, 2 and 3 of CMV strains (Table 1). Briefly, sequenced regions of each virus were recovered using the Nucleotide Sequence Search program located in the Entrez Browser program provided by the NCBI (http://www3.ncbi.nlm.nih.gov/Entrez). Conserved regions of each virus were studied using the similarity search tool Advanced BLAST 2.0, with the BLASTN program (http://www3.ncbi.nlm.nih.gov/blast/). The alignment 
Table 1. Gene specific primer sequence for full-length sequencing of CMV RNAs

\begin{tabular}{|c|c|c|c|}
\hline \multicolumn{2}{|c|}{ Genome Primer } & \multirow{2}{*}{$\begin{array}{l}\text { Sequence } \\
\text { attacaagagcgtacggttcaa } \\
\text { ccgtggtcgtcaaacatca }\end{array}$} & \multirow{2}{*}{$\begin{array}{l}\text { Position } \\
5-763\end{array}$} \\
\hline \multirow{5}{*}{ RNA 1} & $\begin{array}{l}\text { 1-up } \\
\text { 1-down }\end{array}$ & & \\
\hline & $\begin{array}{l}\text { 2-up } \\
\text { 2-down }\end{array}$ & $\begin{array}{l}\text { caagcccactttgctat } \\
\text { ataacaatggtagatgattt }\end{array}$ & $624-1303$ \\
\hline & $\begin{array}{l}\text { 3-up } \\
\text { 3-down }\end{array}$ & $\begin{array}{l}\text { tggatggaacaattcaaggttat } \\
\text { tcttgggeggac }(\mathrm{t}) \text { ttcttgttcgc }\end{array}$ & $1242-2329$ \\
\hline & $\begin{array}{l}\text { 4-up } \\
\text { 4-down }\end{array}$ & $\begin{array}{l}\text { ggcgggt(c)ggtgat(c)gacaag(a)agaaa } \\
\text { accagggtcacatgatcttc }\end{array}$ & $a_{1942-2928}$ \\
\hline & $\begin{array}{l}\text { 5-up } \\
\text { 5-down }\end{array}$ & $\begin{array}{l}\text { cttgtgcgttta }(g) \text { atggctacgaaggc } \\
\text { cacggaccgaagtccttccgaagaaa }\end{array}$ & $2646-3283$ \\
\hline \multirow{4}{*}{ RNA 2} & $\begin{array}{l}\text { 1-up } \\
\text { 1-down }\end{array}$ & $\begin{array}{l}\text { gtttatttacaagagcgtacggttcaa } \\
\text { gtcctctcagcgcacgatttctt }\end{array}$ & $1-752$ \\
\hline & $\begin{array}{l}\text { 2-up } \\
\text { 2-down }\end{array}$ & $\begin{array}{l}\text { acatgatcatgtaccagtgccc } \\
\text { atgaag(a)aatctctcagccacagc }\end{array}$ & $680-1245$ \\
\hline & $\begin{array}{l}\text { 3-up } \\
\text { 3-down }\end{array}$ & $\begin{array}{l}\text { acgaaggaggtccttacagc } \\
\text { ttaaaggcgcctaacattaa }\end{array}$ & $1135-2282$ \\
\hline & $\begin{array}{l}\text { 4-up } \\
\text { 4-down }\end{array}$ & $\begin{array}{l}\text { ttgttgatcgattgaagttt } \\
\text { ctagaagtacacggaccgaa }\end{array}$ & $2160-3035$ \\
\hline \multirow{3}{*}{ RNA 3} & $\begin{array}{l}\text { 1-up } \\
\text { 1-down }\end{array}$ & $\begin{array}{l}\text { gtaatctacactgtgtgtgtgcg } \\
\text { atcttcgcgttcgttaaca }\end{array}$ & $3-836$ \\
\hline & $\begin{array}{l}\text { 2-up } \\
\text { 2-down }\end{array}$ & $\begin{array}{l}\text { gctcgcctgttgaagtcgca } \\
\text { ccacacggtagaatcaaat }\end{array}$ & $769-1623$ \\
\hline & $\begin{array}{l}\text { 3-up } \\
\text { 3-down }\end{array}$ & $\begin{array}{l}\text { aagaaa }(\mathrm{g}) \mathrm{cttg} t \mathrm{ttcg} c g c a t t \\
\text { tggtctccttttga }(\mathrm{g}) \text { aggccccca }\end{array}$ & $1555-2134$ \\
\hline
\end{tabular}

view was performed as master-slave with identities to analyses significant nucleotide homologies in the molecular data retrieved from NCBI's integrated databases, GenBank, EMBL and DDBJ. End sequences of the genomes were obtained with the $5^{\prime} / 3^{\prime}$ rapid amplification of cDNA ends (RACE) protocol (Boehringer Mannheim, Mannheim, Germany). cDNA clones containing the $5^{\prime}$ end of the genomes were obtained using oligo $\mathrm{dC}$ primers and 5cmvR1 for RNA1 (5'-GTAGTCCTTTATCGCCGTGG-3'); 5cmvR2 for RNA2 (5'-GTTCCAC(A)TTCCTCGGGAGTG-3'); and for 5cmvR3 RNA3 (5'-CTACTGGTACCTTGGAAAGCCAT3') primers complementary to nucleotides 136-155, 149168, and 120-142, respectively, of CMV-Fny strain. In addition, cDNA clones containing the the $3^{\prime}$ end of the genomes were obtained using 3cmvF (5'-ACGGGTTGTCCATCCAGCT T(A)ACG-3') and oligo dT primers.

Viral RNA preparation. Equal volumes of purified virus preparation and VEBA extraction buffer $(0.2 \mathrm{M}$ Tris- $\mathrm{HCl}$ (pH 8.5), $1 \mathrm{M} \mathrm{NaCl}, 1 \% \mathrm{SDS}$ and $2 \mathrm{mM}$ EDTA) were mixed and pulverized. This was extracted twice with phenol:chloroform:isoamyl alcohol (PCI, 25:24:1, v/v/v), and centrifuged at $15,000 \mathrm{rpm}$ for $15 \mathrm{~min}$ at room temperature. The aqueous phase was recovered, and re-extracted once with chloroform:isoamyl alcohol (CI, 24:1, v/v). Viral RNA was precipitated with one-tenth volume of $7.5 \mathrm{M}$ ammonium acetate and 2.5 volumes of cold absolute ethanol and incubated at $-70^{\circ} \mathrm{C}$ for $20 \mathrm{~min}$. After centrifugation, precipitated viral RNA was rinsed with $80 \%$ cold ethanol, and precipitates were dried to remove residual ethanol under speed vacuum machine. The resulting precipitates of viral RNA were dissolved in RNase-free distilled water and used for subsequent procedure (Roossinck et al., 1998).

RT-PCR assay. Total nucleic acids were extracted from infected and healthy $N$. tabacum leaves following Choi et al. (1998) and Wadsworth et al. (1988). The first strand cDNA was synthesized with AMV reverse transcriptase (Promega, USA) and was subjected to thermocycling amplification using Taq DNA polymerase (Promega, USA). Thermocycler was programmed for template denaturation at $94{ }^{\circ} \mathrm{C}$ for $3 \mathrm{~min}$, primer annealing at $55^{\circ} \mathrm{C}$ for $30 \mathrm{sec}$ and DNA synthesis at $72^{\circ} \mathrm{C}$ for $1 \mathrm{~min}$. After 35 cycle of this step, the final $10 \mathrm{~min}$ extension step at $72^{\circ} \mathrm{C}$. Ten microliters of the amplified DNA fragments were separated by electrophoresis on a $1 \%$ agarose gel in $1 \mathrm{X}$ Tris-acetate buffer (TAE) and visualized by staining with ethidium bromide.

Sequencing and pylogenetic analyses. DNA bands of interest were purified using QIAquick PCR gel extraction Kit (Qiagen, USA) and cloned into pGEM-T easy vector (Promega, USA) according to the manufacturer's instructions followed by transformation into Escherichia coli JM109. Recombinant plasmids containing cDNA inserts of the correct sizes were sequenced by dideoxynucleotide chain termination method using the ABI Prism Terminator Cycle Sequencing Ready Reaction Kit and the ABI Prism 3770 genetic analyzer (Perkin Elmer, USA) located at the National Instrumentation Center for Environmental Management (CALS, SNU) according to the manufacturer's instructions. The sequences were compared phylogenetically to other CMV RNA sequences in GenBank and EMBL using the multiple sequence alignment application of DNAMAN version 4.0 (Lynnon Biosoft, Canada) full optimal sequence alignments and neighbor-joining method options of Saitou and Nei (1987) with 1,000 bootstrap replications (Altschul, 1998). Percent nucleotide and amino acid ORF sequence identities between virus isolates were calculated using the distance between all pairs of sequences in the multiple alignments. 


\section{Results}

Virus isolates. Our survey in Goseong area, Gyeongsangnam-do, Korea has revealed about $20 \%$ of the zucchini plants were suffering from virus infections. In summary, the symptoms were yellow mosaic, vein banding, malformation and stunt on leaves (Fig. 1, A, B and C). Necrotic blotching, rings and malformation were observed on fruits (Fig. 1, D and E). A total of 18 zucchini leaf and fruit showing above mentioned symptoms were collected and analyzed (Table 2). In parallel, a weed sample, Hemistepta lyrata Bunge, collected between zucchini growing fields has shown similar symptoms compared to those caused by the CMV-zucchini isolate (Fig. 1, F and G), and, therefore, was also included for analysis. Of the 19 samples tested; 6 of CMV (31.6\%), 10 of mix-infection of CMV+ZYMV $(52.6 \%), 2$ of mix-infection of CMV+WMV (10.5\%), 1 of mix-infection of CMV+ZYMV+WMV (5.3\%) were identi-
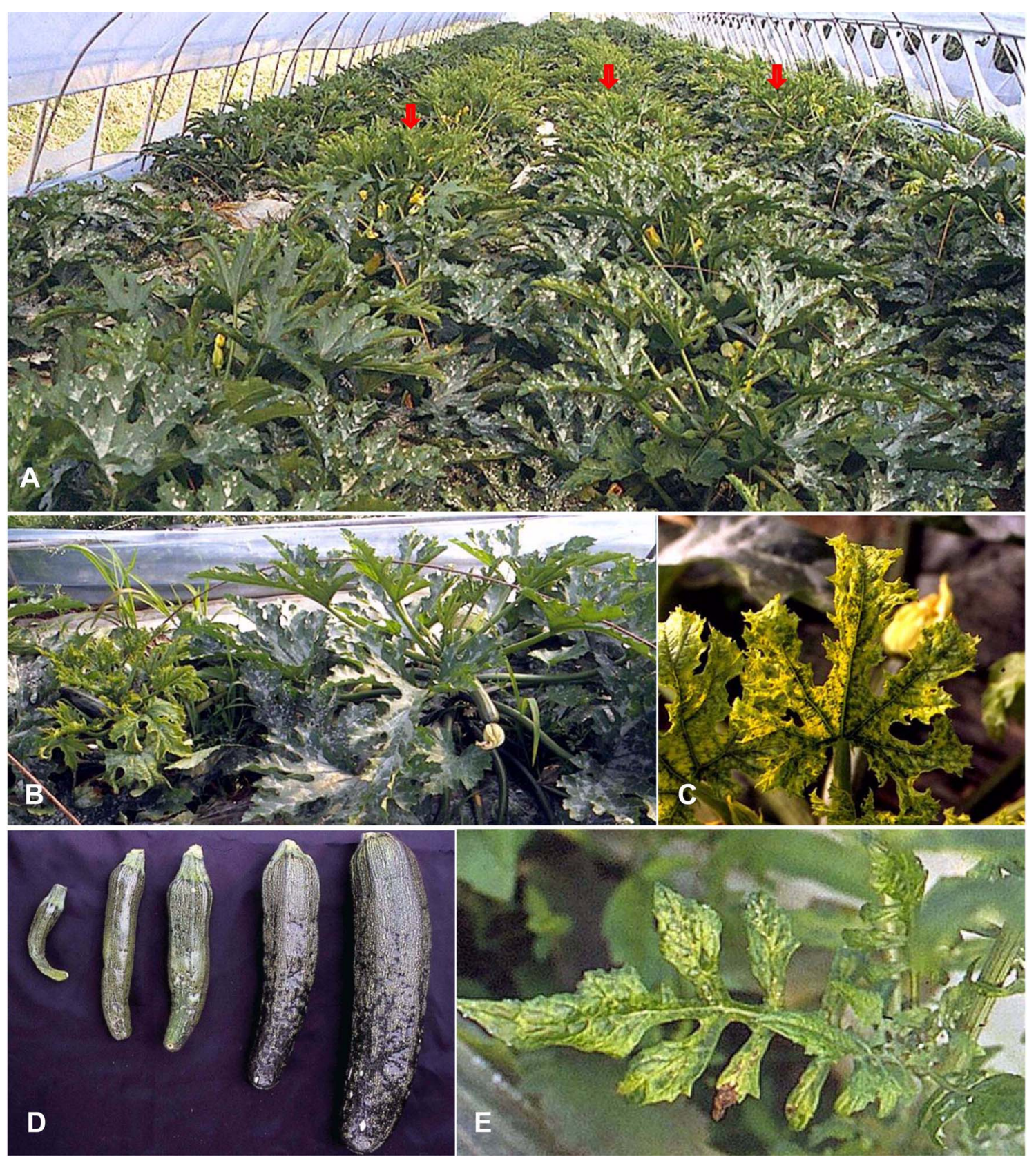

Fig. 1. Viral disease symptoms on zucchini plants. Diseased plants observed in the field (A, arrows), CMV-infected zucchini plants showing yellow mosaic and stunt (B), yellow mosaic and vein banding (C and $\mathrm{E}$ ) on leaves, and necrotic blotching, rings and malformation were observed on fruits (D). 
Table 2. Symptoms on field collected zucchini and weed samples and results confirmed by the ELISA and RT-PCR

\begin{tabular}{|c|c|c|c|c|c|c|}
\hline \multirow{2}{*}{$\begin{array}{c}\text { Sample } \\
\mathrm{No}^{\mathrm{a}}\end{array}$} & \multirow{2}{*}{ Symptom $^{\mathrm{b}}$} & \multirow{2}{*}{$\mathrm{EM}^{\mathrm{c}}$} & \multirow{2}{*}{$\frac{\text { ELISA }^{\mathrm{d}}}{\mathrm{CMV}}$} & \multicolumn{3}{|c|}{ RT-PCR $^{\mathrm{e}}$} \\
\hline & & & & CMV & ZYMV & WMV \\
\hline Z-1-L & ym, mal, stunt & FR & + & + & + & - \\
\hline $\mathrm{Z}-1-\mathrm{F}$ & mal, y & - & + & + & - & - \\
\hline Z-2-L & $\mathrm{m}$, mal, stunt & - & + & + & - & + \\
\hline Z-2-F & $\mathrm{m}, \mathrm{mal}$ & - & + & + & - & - \\
\hline Z-3-L & $\mathrm{m}$, mal, stunt & - & + & + & + & - \\
\hline Z-3-F & $\mathrm{m}, \mathrm{mal}$ & - & + & + & - & - \\
\hline Z-4-L & m, mal, stunt & - & + & + & - & - \\
\hline Z-4-F & $\mathrm{m}, \mathrm{mal}$ & - & + & + & + & - \\
\hline Z-5-L & $\mathrm{ym}$, mal, stunt & - & + & + & - & + \\
\hline $\mathrm{Z}-5-\mathrm{F}$ & $\mathrm{m}, \mathrm{mal}$ & - & + & + & + & - \\
\hline Z-6-L & m, mal, stunt & FR & + & + & + & - \\
\hline Z-6-F & $\mathrm{m}, \mathrm{mal}$ & - & + & + & + & - \\
\hline Z-7-L & $\mathrm{ym}$, mal, stunt & FR & + & + & + & - \\
\hline Z-7-F & $\mathrm{m}, \mathrm{mal}$ & FR & + & + & + & - \\
\hline Z-8-L & $\mathrm{m}$, mal, stunt & - & + & + & + & - \\
\hline Z-8-F & $\mathrm{m}, \mathrm{mal}$ & - & + & + & + & - \\
\hline Z-9-L & ym, mal, stunt & - & + & + & - & - \\
\hline Z-9-F & $\mathrm{m}, \mathrm{mal}$ & - & + & + & + & + \\
\hline Hl-1-L & $\mathrm{m}$ & - & + & + & - & - \\
\hline
\end{tabular}

${ }^{\mathrm{a}} \mathrm{L}$, leaf; F, fruit.

${ }^{\mathrm{b}} \mathrm{m}$, mosaic; mal, malformation; ym, yellow mosaic.

${ }^{\mathrm{c}} \mathrm{FR}$, filamentous rod; -, no detection.

${ }^{\mathrm{d}}+$, positive reaction; - , negative reaction.

${ }^{\mathrm{e}}+$, positive reaction; - , negative reaction.

fied by ELISA and RT-PCR (Table 2) indicating a significant number of zucchini plants were suffering from mixedinfections.

Host range studies. The virus isolate characterized in this study (CMV-Z1) was obtained from a naturally infected zucchini plants collected in 1994 near Goseong, Gyeongsangnam-do, Korea, showing severe symptoms of yellow mosaic, vein banding, malformation and stunt on leaves. Because host range analysis could not differentiate 19 field isolates collected from samples showing similar/different symptoms (data not shown), CMV-Z1 isolate representing among CMV-zucchini isolates was further subjected to biological, cytological and molecular analysis. Symptoms induced by the CMV-Z1 isolate on 19 different test plants are summarized in Table 3. CMV-Z1 isolate caused mosaic symptoms in N. tabacum whereas developed necrotic local lesions in Vicia faba, Pisum sativum, Phaseolus vulgaris and Datura stramonium (Fig. 2A). However, CMV-Z1 isolate failed to infect and induce symptoms in Brassica
Table 3. Symptoms developed on indicator plants inoculated with CMV-Z1 isolate

\begin{tabular}{|c|c|c|c|}
\hline Indicator Plant & $\begin{array}{c}\text { Reaction of } \\
\text { CMV-Z1 } \\
\text { isolate }^{\mathrm{a}}\end{array}$ & ELISA $^{\mathrm{b}}$ & RT-PCR ${ }^{c}$ \\
\hline \multicolumn{4}{|l|}{ Solanaceae } \\
\hline Nicotiana tabacum 'Xanthi-nc' & $\mathrm{cl} / \mathrm{m}$ & $*$ & + \\
\hline N. tabacum 'KY - 57' & $\mathrm{cl} / \mathrm{m}$ & $*$ & $*$ \\
\hline$N$. glutinosa & $\mathrm{cl} / \mathrm{m}$ & $*$ & + \\
\hline N. rustica & $\mathrm{cl} / \mathrm{m}$ & $*$ & + \\
\hline Lycopersicon esculentum & $-/ \mathrm{m}, \mathrm{mal}$ & + & + \\
\hline Capsicum аппиит & $-/ \mathrm{m}$ & + & + \\
\hline Datura stramonium & $\mathrm{crl} /-$ & $*$ & + \\
\hline Physalis angulata & -/stunt,m & + & + \\
\hline Solanum melongena & $\mathrm{cl} / \mathrm{m}$ & $*$ & $*$ \\
\hline \multicolumn{4}{|l|}{ Fabaceae } \\
\hline Vicia fava & $\mathrm{nl} /-$ & - & $*$ \\
\hline Pisum sativum & $\mathrm{nl} /-$ & - & * \\
\hline Phaseolus angularis & $-/ \mathrm{m}$ & + & $*$ \\
\hline Phascolus vulgaris & $\mathrm{nl} /-$ & - & $*$ \\
\hline \multicolumn{4}{|l|}{ Chenopodiaceae } \\
\hline Chenopodium amaranticolor & $\mathrm{nl} /-$ & $*$ & $*$ \\
\hline C. quina & $\mathrm{nl} /-$ & $*$ & * \\
\hline Spinacia oleracea L. & $-/ \mathrm{vc}$ & $*$ & $*$ \\
\hline \multicolumn{4}{|l|}{ Brassicaceae } \\
\hline Brassica peckinensis L. & $-1-$ & - & $*$ \\
\hline Raphanus sativus L. & $-1-$ & - & $*$ \\
\hline \multicolumn{4}{|l|}{ Labiatae } \\
\hline Perilla frutescens & $-/ \mathrm{mal}$ & $*$ & + \\
\hline
\end{tabular}

campestris and Raphanus sativus (Table 3). Cucurbita moschata and Cucumis melo tested were found to be susceptible to CMV-Z1 isolate but CMV-paprika isolate could cause only local lesions in all the varieties of Cucurbita moschata (Table 4). Moreover, in Cucurbita pepo cv 'Taeyang' and 'Bulamhouse', CMV-Z1 isolate caused chlorotic local lesions on inoculated leaves 4 to 5 days post-inoculation, followed by severe mosaic, malformation and stunt but CMV-paprika isolate induced only vein clearing and mosaic symptoms (Fig. 2, B and C). However, CMV-Z1 isolate induced chlolotic local and mosaic symptoms on all the 4 cultivas of Cucurbita melo similar to those caused by the CMV-paprika isolate (Kim, 2007) which was used as control isolate for symptom observation (Table 4). 


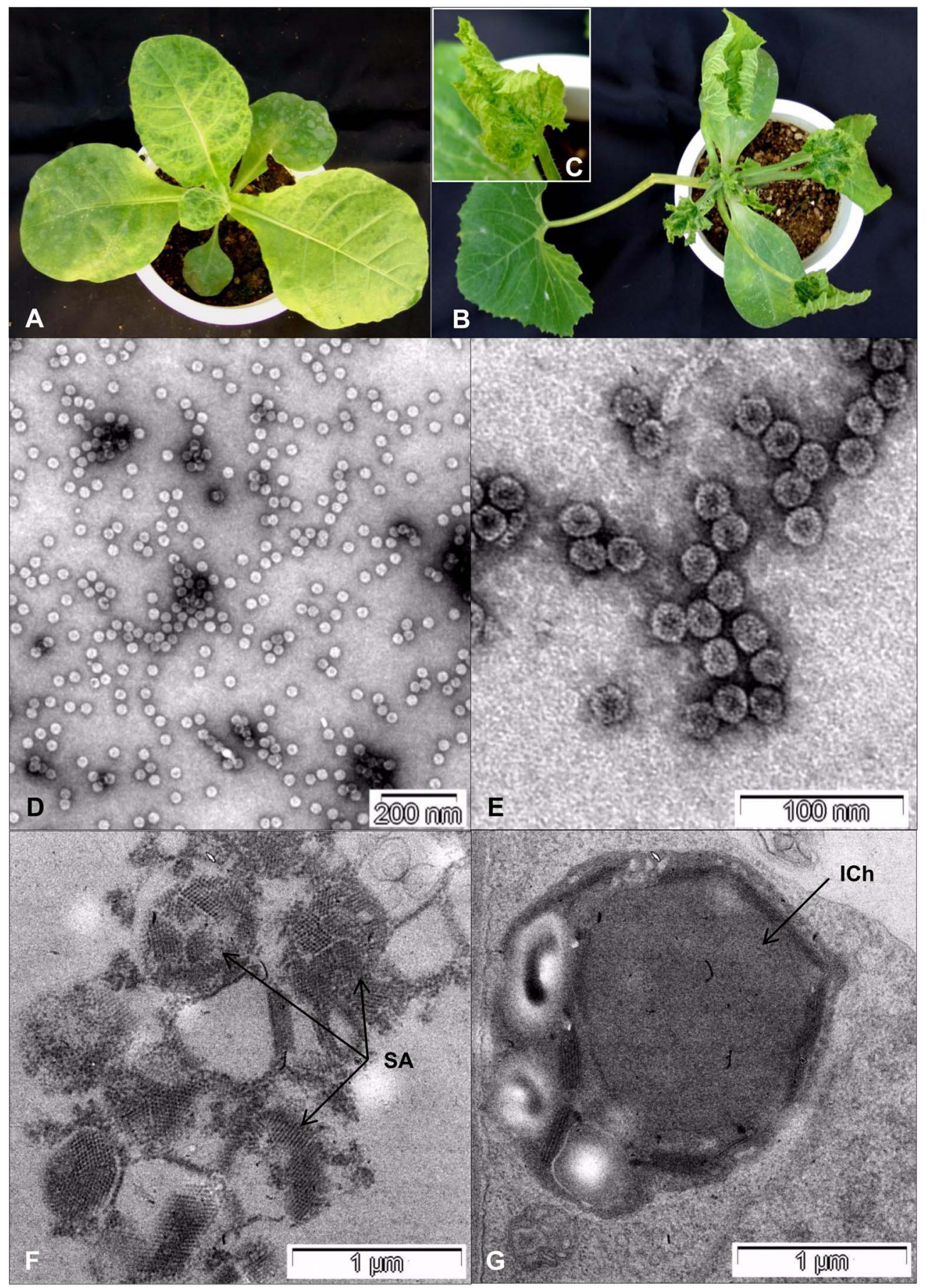

Fig. 2. CMV-Z1 had severe virulence causing severe mosaic on the upper leaves after producing chlorotic spots on the inoculated leaves on Nicotiana tabacum cv. Xanthi-nc (A) and Cucurbita pepo (B and C). Electron micrographs showing purified virus (D and E) and inclusion bodies [spheroidal aggregates (SA) and irregular chloroplasts (ICh)] (F and G).

Virus purification, EM and ELISA. Purified viruses showed the maximum UV absorption at $260 \mathrm{~nm}$ and the minimum at $235 \mathrm{~nm}$. EM of purified viruses revealed spherical virus particles with a diameter of about $30 \mathrm{~nm}$ (Fig. 2, D and E). Two weeks after inoculation, infected leaves were harvested and observed by light and electron microscope. No specific tissue and cell was observed from the leaves in light microscopy. However, thin section examination revealed that virus particles and inclusion bodies in cuticle, epidermis, parenchyma, collenchyma and 
Table 4. Infectivity and symptomsof CMV-Z1 isolate in pumpkin, zucchini and melon cultivars compared to those of CMV-Paprika

\begin{tabular}{|c|c|c|c|c|}
\hline \multirow{2}{*}{ Indicator } & \multicolumn{4}{|c|}{ Reaction $^{\mathrm{a}}$ of } \\
\hline & \multicolumn{2}{|c|}{ Zucchini } & \multicolumn{2}{|c|}{ Paprika } \\
\hline Cucurbita pepo cv 'Taeyang' & $\mathrm{cl} / \mathrm{sm}, \mathrm{mal}$, stunt & $12 / 12$ & $\mathrm{cl} / \mathrm{m}$ & $12 / 12$ \\
\hline 'Bulamhouse' & $\mathrm{cl} / \mathrm{sm}$, mal, stunt & $12 / 12$ & $\mathrm{cl} / \mathrm{vc}, \mathrm{m}$ & $12 / 12$ \\
\hline C. moschata cv 'Jinhan Aihobag' & $\mathrm{cl} / \mathrm{vc}$ & $4 / 11$ & $\mathrm{cl} /-$ & $12 / 12$ \\
\hline 'Nongwoojosaeong' & $\mathrm{cl} / \mathrm{cl}, \mathrm{ve}$ & $6 / 11$ & $\mathrm{cl} /-$ & $12 / 12$ \\
\hline 'Bulameolluk Aihobag' & $\mathrm{cl} / \mathrm{cl}, \mathrm{vc}$ & $6 / 6$ & $\mathrm{cl} /-$ & $6 / 6$ \\
\hline Cucumis melo cv 'Netian-I' & $\mathrm{cl} / \mathrm{cl}, \mathrm{m}$ & $12 / 12$ & $\mathrm{cl} / \mathrm{m}$ & $12 / 12$ \\
\hline 'Best' & $\mathrm{cl} / \mathrm{m}$ & $12 / 12$ & $\mathrm{cl} / \mathrm{cl}, \mathrm{m}$ & $12 / 12$ \\
\hline 'Beauty’' & $\mathrm{cl} / \mathrm{m}$ & $12 / 12$ & $\mathrm{cl} / \mathrm{cl}, \mathrm{m}$ & $12 / 12$ \\
\hline 'Keumssaragi' & $\mathrm{cl} / \mathrm{m}$ & $12 / 12$ & $\mathrm{cl} / \mathrm{m}$ & $12 / 12$ \\
\hline
\end{tabular}

${ }^{\mathrm{a}} \mathrm{NL}$, necrotic local; PP, pin point; M, mosaic; CL, chlorotic local; vc, vein clearing; CRL, cholorotic ring local; Mal, malformation; sM, severe mosaic; -, no symptom; Number of plants infected/number of plants mechanically inoculated.

vacuole of infected cells. Those particle and inclusion bodies were but not found in nuclei, mitochondria and chloroplasts. CMV-Z1 isolate induced specific cytoplasmic inclusion bodies in cell of $N$. tabacum cv. Xanthi-nc: irregular clumps (IC), crystal (Cr) and irregular chloroplasts (ICh). IC was made up of virus particles interspersed with a darkly staining amorphous material and found in the cytoplasm and vacuoles of infected cells, whereas SA and $\mathrm{Cr}$ were rarely found in the vacuoles (Fig. 2, F and G). Virus was easily detected by ELISA and no false positive or negative were found with this method (data not shown).

Nucleotide sequence of CMV-Z1 isolate. We analyzed the complete genome of CMV-Z1 isolate by cDNA cloning. At least three cDNA clones of the corresponding genome region for each RNA segment were selected and sequenced. The genomes of CMV-Z1 RNAs 1, 2 and 3 were found to consist of about $3.3 \mathrm{~kb}, 3 \mathrm{~kb}$, and $2.2 \mathrm{~kb}$ and were deposited at the GenBank under accession codes GU327366, GU327367, and GU327368, respectively. The genomes of CMV-Z1 RNA 1 were found to consist of 3359 nt encoding 1a protein of 993 amino acids (aa) for RNA helicase and methyl transferase starts from an ATG and terminates with an amber stop codon TAG In phylogenetic analysis of nucleotide sequences of RNA 1, CMV-Z1 isolate belonged to subgroup IA (Fig. 3A). The pairwise amino acid sequence identity of the 1a ORF revealed that CMV-Z1 isolate belonged to subgroup I showing over $95.2 \%$ sequence identity, while showing $84.4 \%$ and $83.7 \%$ sequence identity with CMV-Ls (AF416899); CMV-Ly (AF198101), respectively (Table 5).

The CMV-Z1 RNA 2 is $3050 \mathrm{nt}$ in length, containing two partially overlapped ORFs $2 a$ and $2 b$. Sequence identity analyses among RNA2, 2a (857 aa) and 2b (110 aa) of CMV-Z1 isolate revealed that CMV-Z1 isolate have more closely relationship to subgroup IA (with over 95\% sequence identity) than to IB (less than $93 \%$ identity) and subgroup II (less than 75\% identity) (Fig 3B). RNA3 contains $2215 \mathrm{nt}$, encoding 3a protein (movement protein, MP, 279 aa) and coat protein (CP, $218 \mathrm{aa}$ ), corresponding to the nt sequences from 120 to 965 and 1257 to 1913, respectively. Phylogenetic analyses of nucleotide sequences of CMV-Z1 RNA 3 showed a pattern very similar to the CMV-Z1 RNA 2 (Fig 3, B and C). Based on amino acid sequence identity of CMV-Z1 CP ORF among subgroup IA and IB was equally from $96.3 \%$ to $98.6 \%$, while showing $78.9 \%$ and $79.4 \%$ homology with CMV-Ls and with CMVLy, respectively (Table 5). In our sequence analyses, we observed three aa differences between CP protein of CMVZ1 and CMV-paprika isolate at positions 28, 65 and 204 out of 218 amino acids and one aa difference of $3 \mathrm{a}$ protein at position 252 out of 279 amino acids (data not shown). However, sequence identity of CMV-Z1 MP revealed more close relationship to subgroup IA ( $>99.3 \%)$ than to IB $(<96.8 \%)$ and subgroup II $(<83.9 \%)$.

In addition, 5'-noncoding region (NCR) sequence identity of CMV-Z1 RNAs 1 (94nt), 2 (86nt) and 3 (119nt) among subgroup IA and IB was from $81.7 \%$ to $97.9 \%$, while showing $<74.7 \%$ homology with subgroup II. However, the 3'NCR sequence identity of CMV-Z1 RNA 1 (283nt), 2 (390nt) and 3 (301nt) among subgroup IA ranged from $90.6 \%$ to $100 \%$, while $85.6-91.8 \%$ with subgroup IB and $58.1-67.1 \%$ with subgroup II. Altogether, phylogenetic analyses of nucleotide sequences of CMV-Z1 isolate showed that it is more closely related to subgroup IA than to subgroup IB or II.

\section{Discussion}

The zucchini disease incidence around Goseong, Gyeongsangnam-do, Korea was about $20 \%$ and a total of 19 samples including 18 zucchini and 1 weed samples show- 

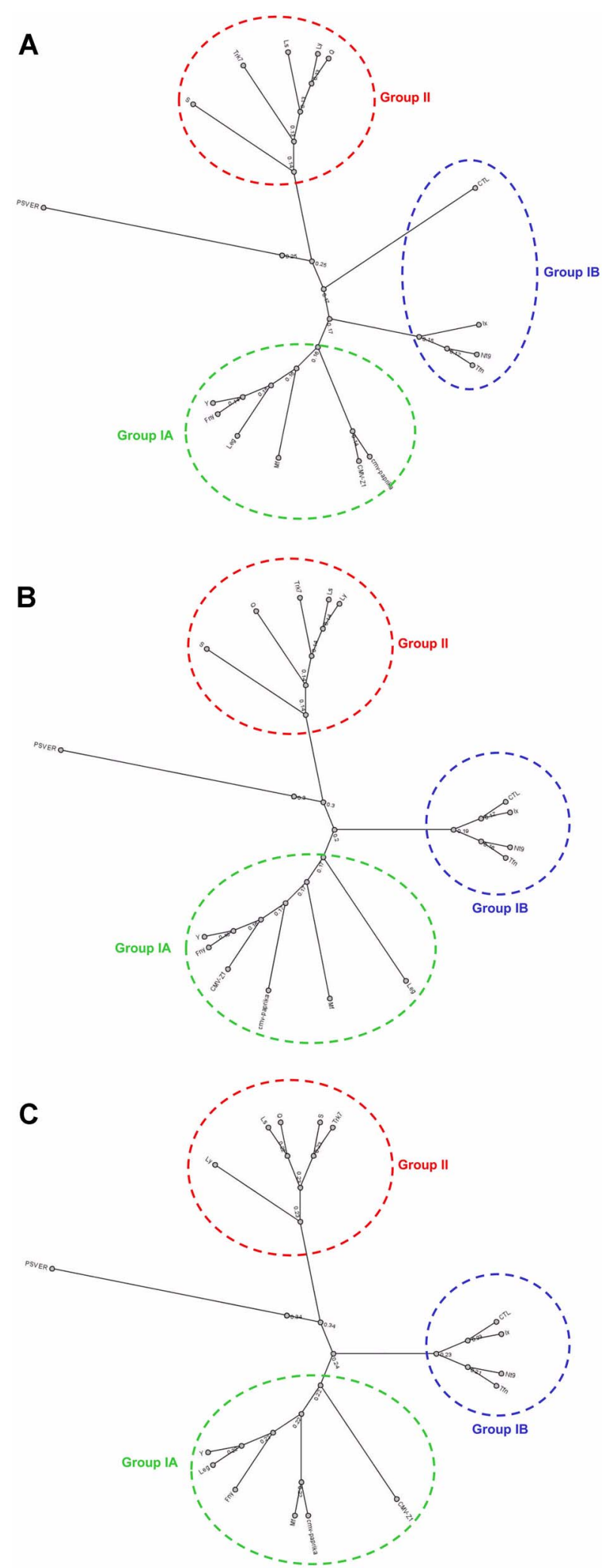

Fig. 3. Neighbor-joining phylogenetic trees base on Jukes-Cantor genetic distances derived from nucleotide sequences of the RNA segments 1,2 and 3 of CMV-Z1 with previously reported CMV isolates (panels A, B, and $\mathrm{C}$, respectively). Peamut stunt virus (PSV) was used as an outgroup. ing viral symptoms such as mosaic, yellow mosaic, stunt and malformation revealed $100 \% \mathrm{CMV}$ infection, i.e. 6 CMV single infection, 10 mix-infection of CMV+ZYMV, 2 mix-infection of CMV+WMV, 1 mix-infection of CMV+ ZYMV+WMV. Van Regenmortel et al. (2000) found that CMV and ZYMV cause considerable damage worldwide in cucurbit fields, either by single or double infections. Although 19 field isolates showed different symptoms, host range analysis those isolates did not reveal clear difference but showed similar symptoms. CMV-Z1 isolate caused mosaic symptoms in Cucurbita moschata and Cucumis melo. Moreover, CMV-Z1 isolate caused severe mosaic, malformation and stunt symptoms in Cucurbita pepo cv 'Taeyang' and 'Bulamhouse', but induced only mosaic symptoms on all the 4 cultivas of Cucumis melo.

Mixed infections occur commonly in nature and may result in a range of effects on the infected host such as on the levels of virus accumulation and on degrees of movement of either of the viruses involved (Shukla et al., 1994; Van Regenmortel et al., 2000). However, mixed infections with CMV and ZYMV causing severe mosaic, malformation and stunt symptoms growing zucchini fields were peculiarly similar to those of caused by single infection of CMV-Z1 isolate. Additionally, CMV-paprika isolate could cause only local lesions in all the varieties of Cucurbita moschata and induce only vein clearing and mosaic symptoms in Cucurbita pepo, but similar to those on all the 4 cultivas of Cucumis melo caused by the CMV$\mathrm{Z} 1$ isolate. It has been suggested that viral proteins encoded by RNA3 of CMV are severity and determinant symptom in various hosts (Li et al., 1999; Palukaitis et al., 1997; Zhang et al., 1994). Gal-On et al. (1996) suggested that two amino acid at positions 51 and 240 of 3 a gene for CMVFny strain play a role in virus-host interaction and determine host range. In addition, it has been reported that three aa positions at 234, 239, and 250 in the 3a protein of LKCMV RNA3 are important for determining symptoms on zucchini squash (Choi et al., 2008). Interestingly, we observed one aa difference at positions 252 of 3 a protein between CMV-Z1 and CMV-paprika isolate suggesting that this aa substitution might be crucial factor for showing symptom variation. More detailed molecular characterization of the CMV-Z1 isolate will be required to further define different pathological characteristics.

In phylogenetic analysis of nucleotide sequences of the RNAs 1, 2 and 3, CMV-Z1 isolate belonged to subgroup IA. Interestingly, RNA1 of CMV-Z1 and CMV-paprika isolate showed more close relationship to strains in IA, whereas analysis of RNAs 2 and 3 was not congruent with CMV-paprika isolate although they were grouped to subgroup 1A. In our nucleotide and amino acid sequence identity of CMV-Z1 ORFs, we can observe displayed a 
Table 5. Pairwise nucleotide and amino acid identity of protein encoded by the genome of CMV-Z1 isolate

\begin{tabular}{|c|c|c|c|c|c|c|c|c|c|c|c|}
\hline \multirow{2}{*}{ Sub-group } & \multirow{2}{*}{ Virus $^{\mathrm{a}}$} & \multicolumn{5}{|c|}{ Nucleotide identity (\%) } & \multicolumn{5}{|c|}{ Amino acid identity (\%) } \\
\hline & & 1a & $2 a$ & $2 b$ & MP & $\mathrm{CP}$ & 1a & $2 \mathrm{a}$ & $2 b$ & MP & $\mathrm{CP}$ \\
\hline \multirow{3}{*}{ IA } & CMV-Y & 92.6 & 98.1 & 98.2 & 97.1 & 98.2 & 95.2 & 98.9 & 97.3 & 99.6 & 98.6 \\
\hline & CMV-Fny & 93.2 & 97.8 & 97.3 & 96.9 & 97.1 & 97.4 & 98.4 & 96.4 & 99.3 & 98.6 \\
\hline & CMV-Mf & 90.7 & 96.8 & 95.8 & 96.5 & 97.7 & 95.4 & 97.7 & 94.5 & 99.3 & 98.2 \\
\hline \multirow{3}{*}{ IB } & CMV-Tfn & 90.5 & 90.0 & 87.0 & 93.7 & 95.7 & 96.5 & 92.9 & 81.7 & 96.8 & 98.6 \\
\hline & CMV-Nt9 & 90.7 & 91.6 & 87.0 & 93.6 & 95.7 & 96.6 & 93.1 & 81.7 & 96.8 & 98.2 \\
\hline & CMV-Ix & 90.5 & 91.7 & 86.8 & 92.1 & 93.0 & 95.9 & 91.4 & 76.4 & 95.0 & 96.3 \\
\hline \multirow{2}{*}{ II } & CMV-Ls & 63.1 & 71.6 & 47.7 & 79.9 & 74.3 & 84.4 & 75.2 & 51.0 & 83.5 & 78.9 \\
\hline & CMV-Ly & 62.7 & 71.6 & 47.1 & 80.0 & 74.0 & 83.7 & 74.7 & 50.0 & 83.9 & 79.4 \\
\hline
\end{tabular}

${ }^{a}$ The Genbank accession number of the reference CMV isolates: CMV-Y (D12537, D12538, D12499); CMV-Fny (D00356, D00355, D10538); CMV-Mf (AJ276479, AJ276480, AJ276481); CMV-Tfn (Y16924, Y16925, Y16926); CMV-Nt9 (D28778, D28779, D28780); CMV-Ix (U20220, U20218, U20219); CMV-Ls (AF416899, AF416900, AF4127976); CMV-Ly (AF198101, AF198102, AF198103).

Table 6. Pairwise nucleotide sequence comparison of protein encoded by the genome of CMV-Z1 isolate

\begin{tabular}{clcccccc}
\hline \hline \multirow{2}{*}{$\begin{array}{c}\text { Sub- } \\
\text { group }\end{array}$} & \multirow{2}{*}{ Virus $^{\mathrm{a}}{ }^{2}$} & \multicolumn{3}{c}{ Nucleotide sequence identity (\%) } \\
\cline { 3 - 8 } & & \multicolumn{2}{c}{ RNA1 } & \multicolumn{2}{c}{ RNA2 } & \multicolumn{2}{c}{ RNA3 } \\
\cline { 3 - 8 } & $3^{\prime}$ & $5^{\prime}$ & $3^{\prime}$ & $5^{\prime}$ & $3^{\prime}$ & $5^{\prime}$ \\
\hline \multirow{3}{*}{ IA } & CMV-Y & 96.5 & 95.7 & 100 & 91.9 & 97.7 & 91.5 \\
& CMV-Fny & 96.1 & 97.9 & 99.2 & 90.7 & 97.7 & 93.3 \\
& CMV-Mf & 90.6 & 92.6 & 96.4 & 91.7 & 97.0 & 96.6 \\
\hline \multirow{4}{*}{ IB } & CMV-Tfn & 91.8 & 94.7 & 88.7 & 87.3 & 89.6 & 95.2 \\
& CMV-Nt9 & 91.7 & 94.7 & 88.9 & 87.3 & 90.9 & 95.2 \\
& CMV-Ix & 90.3 & 93.6 & 85.6 & 81.4 & 88.2 & 94.3 \\
\hline \multirow{2}{*}{ II } & CMV-Ls & 59.0 & 74.7 & 58.5 & 67.4 & 67.1 & 49.0 \\
& CMV-Ly & 59.1 & 73.6 & 58.1 & 67.4 & 66.8 & 49.5 \\
\hline
\end{tabular}

a The Genbank accession number of the reference CMV isolates: CMV-Y (D12537, D12538, D12499); CMV-Fny (D00356, D00355, D10538); CMV-Mf (AJ276479, AJ276480, AJ276481); CMV-Tfn (Y16924, Y16925, Y16926); CMV-Nt9 (D28778, D28779, D28780); CMV-Ix (U20220, U20218, U20219); CMV-Ls (AF416899, AF416900, AF4127976); CMV-Ly (AF198101, AF198102, AF198103).

much higher divergence in the $2 \mathrm{a}$ and $2 \mathrm{~b}$ ORFs (Table 5). Also, 3' NTR of CMV-Z1 RNAs 2 and 3 are specific rather than 5' NTR, whereas 3' NTR analysis of RNA 1 was not different from 5' NTR. However, Roossinck (2002) suggested that the trees estimated for ORFs located on the different RNAs of CMV were not congruent and did not completely support the subgrouping indicated by the $\mathrm{CP}$ ORF, but had independent evolutionary histories. The evolutionary trees of the 1a and 3a ORFs were more compact and displayed more branching than the $2 \mathrm{a}$ and $\mathrm{CP}$ ORFs. Also, analysis of the 3' non-translated region (NTR) that is conserved among all RNAs indicated that evolutionary constraints on this region are specific to the RNA component rather than the virus isolates (Roossinck, 2002).
Therefore, these results suggest that $2 \mathrm{a}$ and $2 \mathrm{~b}$ ORFs of RNAs 2 are much higher divergence, but further investigations of CMV isolates will be characterize pathogenicity and their evolution.

EM observation revealed that CMV-Z1 isolate induced specific cytoplasmic inclusion bodies such as irregular clumps (IC), crystal (Cr) and irregular chloroplasts (ICh), but these inclusion bodies were not found in nuclei and mitochondria. ICh was made up of virus particles interspersed with a darkly staining amorphous material and found in the cytoplasm and vacuoles of infected cells, whereas IC and $\mathrm{Cr}$ were rarely found in the vacuoles (Fig. 2, $\mathrm{F}$ and $\mathrm{G})$. These findings are in agreement with earlier reports (Francki, 1985), in which virus particles were identified in the cytoplasm and vacuoles, but not in mitochondria, nuclei, chloroplasts or plasmodesmata. However, specific cytoplasmic inclusion bodies were not similar to those reported by Francki (1985). Further studies involving construction of infectious clone of CMV-Z1 isolate are required in order to identify the function of specific cytoplasmic inclusion bodies.

Altogether, results of this study indicated that the virus isolate causing symptoms of causing stunt, yellowing, severe mosaic, malformation symptoms on leaves and uneven development and malformation on fruits of zucchini was identified as CMV-Z1 belonging to subgroup IA based upon biological, serological, cytopathological and molecular analyses.

\section{Acknowledgements}

This research was supported in part by grants from the Agriculture Specific Research Project (PJ006325200905) funded by the Rural Development Administration; the BioGreen21 Program (PJ0070092009), Rural Development 
Administration to KSW. KMK was supported by graduate fellowship from the Rural Development Administration.

\section{References}

Altschul, S. F. 1998. Generalized affine gap costs for protein sequence alignment. Proteins 32:88-96.

Chaumpluk, P., Sasaki, Y., Nakajima, N. and Nagano, H. 1996. Six new subgroup I members of Japanese cucumber mosaic virus as determined by nucleotide sequence analysis of RNA3's cDNAs. Ann. Phytopathol. Soc. Jpn. 62:40-44.

Choi, H. S. and Ryu, J. K. 2001. Cucumber Mosaic CucumovirusCARNA5 Causing Bud Necrosis on Table Tomato. Plant Pathol. J. 17:169-173.

Choi, J. K., Kim, H. J., Hong, J. S., Kim, D. W. and Lee, S. Y. 1998. Identification and differentiation of cucumber mosaic virus isolates in Korea. Plant Pathol. J. 14:7-12.

Choi, G. S. 2001. Occurrence of two tobamovirus diseases in cucurbits and control measures in Korea. Plant Pathol. J. 17:243-248.

Choi, S. K., Palukaitis, P., Min, B. E., Lee, M. Y., Choi, J. K. and Ryu, K. H. 2005. Cucumber mosaic virus 2 a polymerase and 3 a movement proteins independently affect both virus movement and the timing of symptom development in zucchini squash. J. Gen. Virol. 86:1213-1222.

Doolittle, S. P. 1916. A new infectious mosaic disease of cucumber. Phytopathology 6:145-147.

Edwardson, J. R. and Christie, R. G 1991. Cucumoviruses. 293319. CRC Handbook of viruses infecting legumes. CRC Press.

Francki, R. I. 1985. Plant virus satellites. Annu. Rev. Microbiol. 39:151-174.

Gal-On, A., Kaplan, I. B. and Palukaitis, P. 1996. Characterization of cucumber mosaic virus. II. Identification of movement protein sequences that influence its accumulation and systemic infection in tobacco. Virology 226:354-361.

Jagger, I. C. 1916. Experiments with the cucumber mosaic disease. Phytopathology 6:148-151.

Jin, T. S., Lee, S. H., Park, J. W., Choi, H. S., Kim, S. M., Shin, D. B., Cheon, J. U. and Cha, B. J. 2003. Identification of Papaya Ringspot Potyvirus type $\mathrm{W}$ infecting squash in Korea. Plant Pathol. J. 19:339.

Kim, M. K. 2007. Comparative analyses of Korean isolates of Cucumber mosaic virus. MS. Thesis, Chungbuk National University, Korea.

Lee, S. H. 1981. Studies on virus disease occurring in various crops in Korea. Res Rept. RDA 23:62-74.

Lee, S. H., Kim, S. M., Kim, W. C. and Lee, K. W. 2003. Multiplex reverse transcription polymerase chain reaction assay for simultaneous detection of five cucurbit-infecting viruses. Plant Pathol. J. 19:342.

Li, H. W., Lucy, A. P., Guo, H. S., Li, W. X., Ji, L. H., Wong, S. M. and Ding, S. W. 1999. Strong host resistance targeted against a viral suppressor of the plant gene silencing defense mechanism. EMBO J. 18:2683-2691.
Lot, H. and Kaper, J. M. 1976. Further studies on the RNA component distribution among the nucleoproteins of cucumber mosaic cucumovirus. J. Virol. 69:4746-4751.

Mossop, D. W., Francki, R. I. B. and Grivell, C. J. 1976. Comparative studies on tomato aspermy and cucumber mosaic viruses. V. Purification and properties of a cucumber mosaic virus inducing severe chlorosis. Virology 74:544-546.

Palukaitis, P. and Garcia-Arenal, F. 2003. Cucumoviruses: $A d v$. Virus Res. 62:241-323.

Palukaitis, P. and Kaplan, J. B. 1997. Synergy of virus accumulation and pathology in transgenic plants expressing viral sequences. In: Virus-Resistant Transgenic Plants. Potential Ecological Impact, ed. by M. Tepfer and E. Bulazs, pp. 77-84. Springer, Berlin.

Rizos, H., Gunn, L. V., Rares, R. D. and Gillings, M. R. 1992. Differentiation of cucumber mosaic virus isolates using the polymerase chain reaction. J. Gen. Virol. 73:2099-2103.

Roossinck, M. J. 2001. Cucumber mosaic virus, a model for RNA virus evolution. Mol. Plant Pathol. 2:59-63.

Roossinck, M. J. 2002. Evolutionary history of Cucumber mosaic virus deduced by phylogenetic analyses. J. Virol. 76:33823387.

Roossinck, M. J. and White, P. S. 1998. Cucumovirus isolation and RNA extraction. Methods Mol. Biol. 81:189-196.

Roossinck, M. J., Bujarski, J. and Ding, S. W. 1999. Family Bromoviridae. 923-935.

Saitou, N. and Nei, M. 1987. The neighbor-joining method: a new method for reconstructing phylogenetic trees. Mol. Biol. Evol. 4:406-425.

Shukla, D. D., Ward, C. W. and Brunt, A. A. 1994. The Potyviridae. CAB International, Cambridge, UK.

Suzuki, M., Kuwata, S., Masuta, C. and Takanami, Y. 1991. Point mutation in the coat protein of cucumber mosaic virus affects symptom expression and virion accumulation in tobacco. $J$. Gen. Virol. 76:1791-1799.

Symons, R. H. 1975. Cucumber mosaic virus RNA contains 7methyl guanosine at the 5 '-terminus of all four RNA species. Mol. Biol. Rep. 2:277-285.

Takanami, Y. 1981. A striking change in symptoms on cucumber mosaic virus -infected tobacco plants induced by a satellite RNA. Virology 109:120-136.

Van Regenmortel, M. H. V., Fauquet, C. M., Bishop, D. H. L., Carstens, E. B., Estes, M. K., Lemon, S. M., Maniloff, J., Mayo, M. A., McGeoch, D. J., Pringle, C. R. and Wickner, R. B. 2000. Family Potyviridae. In: Virus Taxonomy, Seventh Report of the International Committee on Taxonomy of Viruses, pp 703-724. Academic Press, San Diego, USA.

Wadsworth, G. J., Redinbaugh, M. G. and Scandalios, J. G. 1988. A procedure for the small-scale isolaion of plants RNA suitable for RNA blot amalysis. Anal. Biochem. 172:279-283.

Wellman, F. L. 1972. Tropical and American Plant Disease. pp. 125-172. The Scarecrow Press, Metuchen, NJ.

Zhang, L., Handa, K. and Palukaitis, P. 1994. Mapping local and systemic symptom determinants of cucumber mosaic cucumovirus in tobacco. J. Gen. Virol. 75:3185-3195. 